\title{
PENGARUH PEMBERDAYAAN PSIKOLOGI TERHADAP PERILAKU INOVATIF
}

\author{
Irma Suryani ${ }^{1, \Xi)}$ Halimatussakdiah $^{2}$, Nidia Sofa ${ }^{3}$ \\ 1,2 Jurusan Ekonomi Manajemen, Fakultas Ekonomi dan Bisnis, Universitas Syiah Kuala \\ ${ }^{3}$ Jurusan Administrasi Niaga, Politeknik Negeri Jakarta \\ e-mail : ${ }^{1}$ irmasuryani@unsyiah.ac.id
}

\begin{abstract}
Linking three dominan factors namely psychological empowerment, innovative work behavior, and intrinsic motivation, this study developed and examined the relationship among them with a mediating factor. Using questionnaire survey from Higher Education Institutions, the study found that pyschological empowerment significantly affect innovative work behavior. In addition, Intrinsic motivation, as anticipated in the study also affect innovative work behavior. Finally, as an intervening variabel, intrinsic motivation enhance the relationship between psychological empowerment and innovative work behavior.
\end{abstract}

Keywords : psychological empowerment, innovative work behavior, and intrinsic motivation

\begin{abstract}
ABSTRAK
Menghubungkan tiga variabel dominan yaitu pemberdayaan psikologis, perilaku kerja inovatif, dan motivasi intrinsik, penelitian ini mengembangkan dan menguji hubungan antara ketiga variabel tersebut dengan variabel mediasi. Menggunakan kuesioner survei dari Perguruan Tinggi, studi ini menemukan bahwa pemberdayaan psikologis secara signifikan mempengaruhi perilaku kerja yang inovatif. Selain itu, motivasi intrinsik, seperti yang diantisipasi dalam penelitian ini juga mempengaruhi perilaku kerja yang inovatif. Akhirnya, sebagai variabel intervening, motivasi intrinsik meningkatkan hubungan antara pemberdayaan psikologis dan perilaku kerja yang inovatif.
\end{abstract}

Kata kunci : pemberdayaan psikologis, perilaku kerja inovatif, dan motivasi intrinsik

\section{PENDAHULUAN}

Perilaku inovatif menjadi salah satu unsur penting dalam meningkatkan performa kinerja (Yuan \& Woodman, 2010). Saat ini menjadi pekerja yang kreatif dan inovatif sangatlah penting dalam mengimbangi tuntutan yang bersifat global dan kompetitif. Kehadiran Masyarakat Ekonomi Asean serta Industri 4.0 memaksa pekerja dalam sebuah organisasi menghasilkan ide-ide yang dapat diaplikasikan serta menjadikan ide tersebut berguna dan berdaya saing tinggi. Salah satu penyumbang tenaga kerja terbesar adalah Universitas. Untuk menciptakan lulusan universitas yang berdaya saing tinggi, tidak hanya sistem perkuliahan yang baik namun juga Universitas membutuhkan dosen yang inovatif dan kreatif (Ferrari et al, 2009). Dalam hal ini diharapkan dosen dapat menciptakan lingkungan belajar yang akan meningkatkan pemahaman dan keahlian mahasiswa yang akan digunakan di dunia kerja nantinya. Selain itu, juga penting untuk dosen menyumbangkan ide kreatif dan inovatif pada kegiatan penelitian dan pengabdian masyarakat yang akhirnya akan berguna untuk kemaslahatan masyarakat.

Banyak faktor yang menjadi pendorong seorang dosen menunjukkan perilaku kreatif dan inovatif (Janssen \& Van Yperen, 2004). Selama ini, banyak faktor yang telah diteliti berdasarkan faktor yang sifatnya berwujud seperti fasilitas kantor, motivasi ekstrinsik, dan lingkungan sosial di sekitar pekerja. Faktor yang sifatnya internal yang melihat kepada motivasi diri seseorang masih kurang perhatian di dalam riset dengan tema perilaku inovatif ini (Shalley, Zhou, \& Oldham, 2004). 
Bahkan penelitian yang melihat perilaku inovatif dosen dengan menggabungkan faktor individu dan faktor sosial juga masih sangat sedikit. Untuk itu, penelitian ini ditujukan untuk melihat apakah perilaku inovatif seorang dosen dipengaruhi oleh pemberdayaan psikologi yang diberikan oleh kampus yang selanjutnya juga di moderasi oleh motivasi intrinsik dari dalam dirinya dosen tersebut.

Penelitian ini menitikberatkan pada literatur kreatifitas dan inovasi serta kaitannya dengan motivasi. Selanjutnya hasil dari penelitian ini akan menjadi sebuah masukan besar dalam riset perilaku inovasi serta memperkuat hubungan antara pemberdayaan psikologi, motivasi intrinsik, dan perilaku inovatif. Studi ini akan memberi kontribusi besar dalam pengembangan teori serta pemahaman dengan unsur variabel-variabel tersebut. Studi Kepustakaan

Perilaku Inovatif

Perilaku Inovatif adalah hasil dari implementasi ide-ide kreatifitas (West \& Farr, 1990). Para ahli menyimpulkan bahwa inovasi adalah langkah kedua setelah kreativitas terjadi yang menunjukkan perilaku komplek dalam menciptakan hasil dari ide kreatif (Janssen 2000). Setelah hadirnya ide-ide yang kreatif, seseorang akan mengeksekusi ide kreatif tersebut kedalam sebuah proses inovasi. Inovasi lebih diinginkan oleh sebuah organisasi terutama organisasi bisnis karena ide-ide baru yang kreatif tidak hanya dimunculkan saja, namun dapat diciptakan menjadi produk, kebijakan, sistem, cara, dll (Woodman et al, 1993).

Perilaku inovatif menjadi penting untuk setiap pekerja terutama dalam studi ini adalah dosen karena perilaku berarti sifat yang dimiliki ditunjukkan dengan sikap dan menjadi perilaku sehari-hari. Dosen yang banyak mengeluarkan ide-ide kreatif, akan menunjukkan perilaku inovatif dari ide-ide tersebut yang akhirnya meningkatkan perilaku inovatif di dalam sikap pekerja tersebut (Oldham \& Cummings, 1996). Karena kreativitas menular, maka diharapkan bahwa sikap inovatif yang dimiliki dosen dalam proses belajar mengajar dapat ditularkan kepada mahasiswa hingga mahasiswa akhirnya menjadi lebih kreatif dan inovatif.

\section{Pemberdayaan Psikologi}

Pemberdayaan psikologi mengandung empat unsur, yaitu: meaningful, competence, choice/self-determination, dan impact. Pekerjaan yang dilakukan bersifat meaningful (Thomas \& Velthouse, 1990) maksudnya adalah pekerjaan itu berarti untuk dirinya dan orang lain. Pekerjaan yang dilakukan akan memberikan banyak arti dan manfaat untuk orang lain. Selfdetermination, komponen ini berarti bahwa seorang pekerja memiliki tujuan diri yang kuat akan pekerjaan yang digelutinya. Seseorang akan merasakan bahwa ketetapan diri yang dimiliki cukup kuat untuk melakukan pekerjaannya. Selanjutnya adalah unsur Competence. Unsur ini dimaksudkan bahwa seseorang dalam menyelesaikan pekerjaannnya memiliki kompetensi sehingga pekerjaan akan dirasakan mudah. Dengan keahlian yang dimiliki seseorang dapat menyelesaikan tugas ataupun pekerjaan yang dibebaninya. Terakhir yaitu komponen impact atau dampak. Seseorang menyadari bahwa hasil dari pekerjaannya memiliki dampak yang signifikan dalam kehidupan masyarakat luas.

Dalam keterkaitannya dengan perilaku inovatif, seorang dosen umumnya memenuhi keempat unsur diatas. Keempat unsur tersebut antara lain pekerjaan yang berarti, tujuan diri yang kuat, kompetensi yang dimiliki, serta dampak dari hasil kerja. Pekerjaan yang berarti bagi dosen terlihat dari keinginan berbagi ilmu kepada mahasiswa, serta pilihan seseorang untuk menjadi dosen 
menguatkan determinasi diri mereka untuk bekerja dengan ikhlas dan yakin dapat menyelesaikan pekerjaan dengan baik (Spreitzer, 1995), serta kompetensi yang telah dibuktikan dengan tingkat pendidikan yang tinggi serta pekerjaan yang memberi dampak terhadap peningkatan sumber daya manusia yang berkompeten di masyarakat (Gilson \& Shalley, 2004).

Keempat unsur diatas menjadi penting dalam kreatifitas seseorang dikarenakan kreatifitas mensyaratkan seseorang untuk memiliki kompetensi diri dan rasa tujuan diri yang tinggi sehingga mampu meningkatkan resiko untuk mendapatkan ide kreatif dan melihat peluang hadirnya ide-ide kreatif secara kognitif (Amabile et al 1996). Sehingga dengan adanya pemberdayaan psikologi maka seseorang akan lebih kreatif dan selanjutnya akan lebih inovatif Gilson \& Shalley, 2004).

\section{H1 : Pemberdayaan \\ Psikologi} mempengaruhi Perilaku inovatif

\section{Motivasi Intrinsik}

Motivasi intrinsik menjadi salah satu faktor penting dalam perilaku kreatif seseorang dalam bekerja (Amabile et al, 1996). Bahkan motivasi intrinsik dalam situasi tertentu menjadi faktor yang lebih dominan dalam penentuan tingkat kepuasan kerja, kreatifitas, serta performan kinerja dalam organisasi (Zhou et al, 2003). Motivasi intrinsik adalah dorongan yang berasal dari dalam diri seseorang yang dapat meningkatkan level kenikmatan dalam melakukan sebuah kegiatan (Deci \& Ryan, 1991). Kreatifitas sangat erat kaitannya dengan motivasi intrinsik. Bahkan salah satu keempat unsur utama kreatifitas menurut Amabile et al (1996) adalah hadirnya motivasi intrinsik.

Seseorang akan menunjukkan perilaku inovatif ketika mereka merasa bahwa pekerjaan yang mereka kerjakan lebih bernilai, memberikan perasaan yang menyenangkan serta memotivasi mereka lebih dalam (Fuller et al, 2006). Perasaan yang menyenangkan dari intrinsic motivation tersebut akan membuat semangat bekerja dan meningkatkan kreatifitas sehingga akhirnya meningkatkan perilaku inovatif seseorang (Woodman et al, 1993).

H2 : Motivasi intinsik mempengaruhi perilaku inovatif

Motivasi intrinsik dipercayai sebagai pengaruh perilaku inovatif, namun motivasi intrinsik tidaklah cukup (Amabile, 1983). Penelitian terdahulu menunjukkan bahwa ada hubungan antara pemberdayaan psikologi dan motivasi intrinsik (Spreitzer, 1996). Pemberdayaan Psikologi dengan empat unsur yang memberikan otoritas lebih dan perasaan senang akan meningkatkan level perilaku kreatifitas dan inovasi lebih tinggi (Zhang \& Bartol, 2010). Dalam hal ini, seseorang yang merasa bahwa dirinya memiliki rasa pemenuhan dan ketetapan diri akan suatu pekerjaan akan meningkatkan kreatifitas dirinya dan selanjutnya akan menujukkan sikap inovatif (Mumford, 2000). Sikap inovatif ini akan didukung dengan motivasi intrinsik yaitu dorongan untuk melakukan sebuah pekerjaan dengan anggapan bahwa mereka dapat melakukan pekerjaan itu dengan baik, dengan hal-hal yang kreatif dan tidak biasa, serta dapat berkonsentrasi dengan pekerjaannya dengan baik (Deci \& Ryan, 2000; Grant, 2008). Perasaan senang dan bahagia inilah yang selanjutnya akan membuat orang menjadi lebih kreatif dan bersemangat untuk mengeksekusi ide kreatif menjadi implementasi produk atau kebijakan atau hal-hal yang bersifat inovatif.

H3 : Pemberdayaan Psikologi mempengaruhi Perilaku Inovatif dimediasi oleh Motivasi Intrinsik

\section{METODE PENELITIAN}

Penelitian ini dilakukan di Universitas Syiah Kuala (Unsyiah), Darussalam, 
Banda Aceh, Aceh. Kami menggunakan kuesioner daring yang diberikan kepada tenaga kependidikan (tendik) berstatus PNS di lingkungan Unsyiah. Kuesioner yang digunakan sudah diadaptasi dari para pakar dan diterjemahkan ke dalam bahasa Indonesia oleh dua ahli bahasa untuk menjaga keabsahan arti dari setiap pertanyaan yang diberikan (Brislin, 1980).

Kuesioner dibagikan kepada Tendik di 12 fakultas di Unsyiah dengan jabatan fungsional mulai dari Asisten Ahli hingga Guru Besar. Dengan melihat data jumlah dosen PNS di Unsyiah melalui laman Unsyiah serta merujuk pada data di bagian personalia, kami memberikan link berisikan kuesioner kepada seluruh dosen melalui grup whatsapp dan email. Terdapat total 230 kuesioner yang terisi, dan data yang dapat digunakan sebanyak 225.

\section{Pengukuran}

Semua variabel diukur berdasarkan respon yang mereka berikan atas pertanyaan-pertanyaan di dalam kuesioner dengan menggunakan skala likert 5 skala. Skala yang dipakai berjarak "sangat setuju” hingga "sangat tidak setuju”. Pemberdayaan psikologi menggunakan pengukuran yang diadaptasi oleh Spreitzer (1995), contoh dari pertanyaan pada kuesioner yaitu: "Pekerjaan yang saya kerjakan sangatlah berarti bagi saya", "Saya percaya diri akan pekerjaan saya," "Dampak dari pekerjaan di departemen saya cukup besar," "Saya memiliki otonomi yang cukup untuk menentukan pekerjaan saya.” Pengukuran Motivasi Intrinsik menggunakan pengukuran yang diadaptasi oleh Alga et al (2006), contoh dari pertanyaan pada kuesioner antara lain: pekerjaan saya menyenangkan, saya rasa pekerjaan saya menarik, saya senang mengerjakan pekerjaan saya. Dan terakhir pengukuran Perilaku Inovatif menggunakan pengukuran yang diadaptasi oleh Janssen (2000), contoh dari pertanyaannya yaitu "saya menciptakan ide-ide kreatif”, "saya mencari peluang untuk berinovasi", "saya suka menciptakan metode, teknik, dan instrumen baru saat bekerja”.

\section{HASIL DAN PEMBAHASAN}

Dalam penelitian ini digunakan alat analisa seperti SEM (Structural Equation Modeling) dengan tujuan menguji model hipotesis. Penggunaan SEM dimaksudkan agar penggunaan alat tes dapat digunakan secara menyeluruh pada keseluruhan sistem variabel di dalam model hipotesis yang ditetapkan sehingga akhirnya asesmen yang akan digunakan akan menunjukkan konsistensi model hipotesis terhadap data yang didapat (Byrne, 1994).

Dalam melakukan tes model hipotesis, kami menggunakan strategi analisa dua langkah oleh Anderson dan Gerbing (1988) yaitu diawali dengan langkah pengujian CFA yaitu confirmatory factor analysis, dan selanjutnya kami menggunakan SEM setelah data diyakinkan fit untuk langkah selanjutnya.

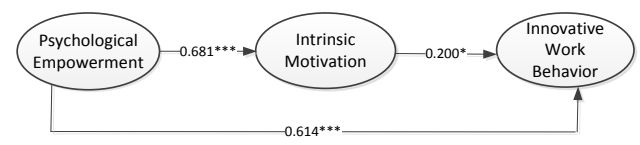

Gambar 1. Hasil Uji

Measurement Model adalah "proses pemodelan dalam penelitian yang diarahkan untuk menyelidiki unidimensionalitas dari indikatorindikator yang menjelaskan sebuah variabel laten” (Hair et al., 2010).

Hasil pengujian tahap pertama, terdapat 3 (tiga) indikator yang mempunyai nilai loading factor lebih kecil dari 0,5 sehingga harus dikeluarkan satu persatu dari model karena tidak memenuhi 
kriteria yang disyaratkan, kemudian model tersebut diuji kembali.

Hasil komputasi AMOS untuk measurement model pada tahap kedua sudah menghasilkan nilai loading factor yang memenuhi standar yang disyaratkan yaitu lebih besar dari 0,5 sehingga dapat dilakukan uji struktural model.

Pengujian tahap selanjutnya adalah uji normalitas data. Evaluasi terhadap normalitas data dilakukan dengan menggunakan kiteria nilai "critical ratio skewness multivariate" $\pm 2,58$ pada tingkat signifikansi 0,01.

Hasil pengujian terhadap normalitas data menunjukkan bahwa data terdistribusi secara normal karena nilai "critical ratio skewness multivariate" berada dalam rentang nilai $\pm 2,58$.

Pengujian structural equation model dilakukan dengan dua pengujian, yaitu uji kesesuaian model dan uji signifikansi kausalitas melalui uji koefisien regresi (Hair et al., 2010). Hasil uji kausalitas sebagaimana ditunjukkan pada Gambar 1.

\section{Pengaruh Antar Variabel Uji Kesesuaian Model (Goodness-of- fit Test)}

Berdasarkan perhitungan AMOS untuk model struktural, dihasilkan indeksindeks goodness-of-fit yang baik dan dapat diterima karena model sudah fit setelah dilakukan modifikasi indeks sebagaimana ditunjukkan dalam Tabel 1.

Tabel 1. Goodness-of-fit Index Structural Model

\begin{tabular}{|c|c|c|c|}
\hline $\begin{array}{l}\text { Goodness-of-fit } \\
\text { Index }\end{array}$ & $\begin{array}{l}\text { Cut-off } \\
\text { Value }\end{array}$ & $\begin{array}{l}\text { Hasil } \\
\text { Model }\end{array}$ & Keterangan \\
\hline RMSEA & $\leq 0,08$ & 0,076 & Baik \\
\hline GFI & $\geq 0,90$ & 0,934 & Baik \\
\hline AGFI & $\geq 0,90$ & 0,893 & Marginal \\
\hline $\begin{array}{l}\text { Relative } \\
\text { (CMIN-DF) }\end{array}$ & $\leq 2,00$ & 2.229 & Baik \\
\hline TLI & $\geq 0,90$ & 0,953 & Baik \\
\hline CFI & $\geq 0,90$ & 0,966 & Baik \\
\hline
\end{tabular}

Sumber: Hasil Penelitian, 2020 (diolah)

\section{Uji Signifikasi Kausalitas}

Model struktural adalah hubungan antar konstruk yang mempunyai hubungan sebab akibat (causal), dengan demikian ada variabel independen dan variabel dependen. Hubungan antar variabel ini dapat dilihat melalui angka-angka koefisien statistik hasil perhitungan AMOS sebagaimana ditampilkan pada Tabel 2.

Tabel 2. Regression Weights Analisis Jalur Regression Weights: (Group number 1 Default model)

\begin{tabular}{|c|c|c|c|c|c|c|}
\hline & & & $\begin{array}{r}\text { Stdzd. } \\
\text { Estim } \\
\text { ate }\end{array}$ & S.E. & C.R. & $\mathrm{P}$ \\
\hline $\begin{array}{l}\text { Intrinsic_- } \\
\text { Motivation }\end{array}$ & $<--$ & $\begin{array}{l}\text { Psycholo } \\
\text { gical_E } \\
\text { mpower } \\
\text { ment }\end{array}$ & 681 & 103 & 5,641 & $* * *$ \\
\hline $\begin{array}{l}\text { Innovative } \\
\text { _Work_Be } \\
\text { havior }\end{array}$ & $<--$ & $\begin{array}{l}\text { Psycholo } \\
\text { gical_E } \\
\text { mpower } \\
\text { ment }\end{array}$ & ,614 & 160 & 4,504 & $* * *$ \\
\hline $\begin{array}{l}\text { Innovative } \\
\text { _Work_Be } \\
\text { havior }\end{array}$ & $<--$ & $\begin{array}{l}\text { Intrinsic } \\
\text { Motivat } \\
\text { ion }\end{array}$ & ,200 & 146 & 1,879 & ,050 \\
\hline
\end{tabular}

Sumber: Hasil Penelitian, 2020 (diolah)

Tabel 3. Analisis Jalur Model Penelitian

\begin{tabular}{|c|c|c|c|c|}
\hline No & Analisis Jalur & $\begin{array}{l}\text { Penga } \\
\text { ruh } \\
\text { Langs } \\
\text { ung }\end{array}$ & $\begin{array}{l}\text { Penga } \\
\text { ruh } \\
\text { tdk } \\
\text { Langs } \\
\text { ung }\end{array}$ & $\begin{array}{l}\text { Ketera } \\
\text { ngan }\end{array}$ \\
\hline 1 & $\begin{array}{l}\text { Psychological_Em } \\
\text { powerment } \rightarrow \\
\text { Intrinsic } \\
\text { Motivation }\end{array}$ & $\begin{array}{c}0.681^{*} \\
* *\end{array}$ & - & $\begin{array}{l}\text { Signifik } \\
\text { an }\end{array}$ \\
\hline 2 & $\begin{array}{l}\text { Psychological_Em } \\
\text { powerment } \rightarrow \\
\text { Innovative Work } \\
\text { Behavior }\end{array}$ & $\underset{* *}{0.614^{*}}$ & - & $\begin{array}{l}\text { Signifik } \\
\text { an }\end{array}$ \\
\hline 3 & $\begin{array}{l}\text { Intrinsic_Motivati } \\
\text { on } \rightarrow \text { Innovative } \\
\text { Work Behavior }\end{array}$ & $\underset{*}{0.200^{*}}$ & - & $\begin{array}{l}\text { Signifik } \\
\text { an }\end{array}$ \\
\hline 4 & $\begin{array}{l}\text { Psychological_Em } \\
\text { powerment } \\
\text { Intrinsic } \\
\text { Motivation } \\
\text { Innovative } \\
\text { Behavior }\end{array}$ & - & $\underset{*}{0,146^{*}}$ & $\begin{array}{l}\text { Signifik } \\
\text { an }\end{array}$ \\
\hline
\end{tabular}

Dalam penelitian ini, kami menghasilkan beberapa temuan serta kontribusi. Yang pertama kami telah menghasilkan sebuah model konseptual yang khusus menghubungkan antara teori pemberdayaan psikologi dan kaitannya dengan perilaku inovasi. Meskipun penelitian sebelumnya telah memberikan kontribusi serupa, namun keunikan dari penelitian ini adalah hubungan yang 
didapat antara variabel melihat konteks pada Perguruan Tinggi.

Selanjutnya, hasil penelitian ini juga memberikan kontribusi pada literatur motivasi, pemberdayaan psikolog, serta perilaku inovasi yang dapat disimpulkan bahwa pemberdayaan psikologi secara signifikan mempengaruhi perilaku inovasi pada dosen di Universitas Syiah Kuala. Hasil penelitian ini mendukung secara penuh penelitian sebelumnya yang juga menyimpulkan bahwa pemberdayaan psikologi memberi dampak pada perilaku inovasi karyawan di sebuah organisasi. Kehadiran variabel intervening yaitu motivasi intrinsik juga memberikan pengaruh yang lebih kuat antara variabel pemberdayaan psikologi dan perilaku inovasi. Hal ini memberikan penegasan yang lebih dalam terhadap penelitian sebelumnya yang menyatakan bahwa motivasi intrinsik sebagai faktor mediasi dapat mempererat hubungan antara variabel pemberdayaan psikologi dan perilaku inovasi.

Salah satu penyebab hasil yang signifikan antara pemberdayaan psikologi dan perilaku inovasi yaitu dikarena pemberdayaan psikologi yang terdiri dari empat unsur antara lain "merasa melakukan pekerjaan yang berarti," "mampu dalam melakukan pekerjaan," "pekerjaan berdampak untuk diri sendiri dan orang banyak," serta "ketetapan diri atau keyakinan diri". Keempat unsur ini memberikan rasa otonomi yang kuat agar seseorang merasa terpenuhi secara lahiriah dan menghasilkan ide-ide yang kreatif (Oldham \& Cummings, 1996), serta langkah selanjutnya percaya diri untuk mengimplementasikan ide tersebut melalui perilaku inovatif.

Selanjutnya, hadirnya motivasi intrinsik dari dalam diri seseorang memperkuat hubungan pemberdayaan psikologi dan perilaku inovasi. Penelitian ini mendukung penelitian sebelumnya yang menyatakan bahwa motivasi intrinsik memberikan pengaruh mediasi terhadap hubungan antara kepemimpinan dan perilaku inovatif dimana kepemimpinan yang bersifat etikal memberikan otonomi selayaknya pemberdayaan psikologi (Yidong \& Xinxin, 2013). Perasaan bahagia dari motivasi intrinsik membuat seseorang dengan otonomi dari pemberdayaan psikologi semakin merasa nyaman untuk berinovasi dalam praktek kerjanya (Munton \& West, 1995). Rasa nyaman dalam berinovasi membuat mereka semakin bahagia dan melihat pekerjaannya menyenangkan dan menggairahkan.

Studi ini memberikan saran kepada pihak pimpinan dalam Perguruan Tinggi baik negeri maupun swasta untuk mempertimbangkan beberapa hal. Pertama, pemberdayaan psikologi cukuplah penting untuk meningkatkan perilaku inovasi di dalam kinerja tridarma perguruan tinggi dosen. Sehingga penting untuk pihak pimpinan memperhatikan empat unsur pemberdayaan psikologi yang dapat merangsang perilaku inovasi tersebut. Kedua, pihak pimpinan dapat memastikan bahwa tidak hanya motivasi ekstrinsik yang dapat diandalkan di dalam peningkatan perilaku inovasi, namun juga motivasi intrinsik di dalam diri dosen. Dosen-dosen dengan motivasi internal diri yang tinggi, akan melihat pekerjaan mereka sebagai pekerjaan yang menyenangkan sehingga mereka akan bersemangat untuk menjadi lebih inovatif.

Penelitian ini juga tidak lepas dari batasan-batasan selama penelitian ini dilakukan. Diantaranya adalah rentang waktu yang digunakan oleh peneliti saat mengambil sampel serta pengisian kuesioner cukuplah terbatas. Sehingga penelitian selanjutnya dapat melihat sampel dengan skala yang lebih besar serta rentang waktu yang lebih lama.

\section{KESIMPULAN}


Hasil yang didapat dari studi ini adalah adanya hubungan yang erat serta signifikan antara pemberdayaan psikologi dan perilaku inovasi, serta kedua konstruk tersebut juga berpengaruh signifikan terhadap variabel intervening motivasi intrinsik yang mana variabel ini juga menguatkan hubungan kedua variabel tersebut.

\section{DAFTAR PUSTAKA}

[1] Amabile, T. M. 1983. The social psychology of creativity: A componential conceptualization. Journal of Personality and Social Psychology, 45: 357-376.

[2] Amabile, T. M., Conti, R., Coon, H., Lazenby, J., \& Herron, M. 1996. Assessing the work environment for creativity. Academy of Management Journal, 39(5), 1154-1184.

[3] Anderson, J. C., \& Gerbing, D. W. 1988. Structural equation modeling in practice: A review and recommended two step approach. Psychological Bulletin, 103: 411423.

[4] Brislin, R. W. 1980. Translation and content analysis of oral and written materials. In H. C. Triandis \& J. W. Berry (Eds.), Handbook of crosscultural psychology (pp. 389-444). Boston: Allyn and Bacon.

[5] Deci, E. L., \& Ryan, R. M. 1991. A motivational approach to self: Integration in personality. In $\mathrm{R}$. Dienstbier (Ed.), Nebraska symposium on motivation, vol. 38: 237-288. Lincoln: University of Nebraska Press. Nebraska

[6] Deci, E. L., \& Ryan, R. M. 2000. The 'what' and 'why' of goal pursuits: human needs and the selfdetermination of behavior. Psychological Inquiry, 11, 227-268.

[7] Ferrari A., Cachia, R., \& Punie Yves. 2009. Innovation and Creativity in Education and Training in the EU Member States: Fostering Creative
Learning and Supporting Innovative Teaching. JRC Technical Notes. European Commission Joint Research Centre Institute for Prospective Technological Studies.

[8] Fuller, J. B., Marler, L. E., \& Hester, K. 2006. Promoting felt responsibility for constructive change and proactive behavior: Exploring aspects of an elaborated model of work design. Journal of Organizational Behavior, 27(8), 1089-1120.

[9] Janssen, O., Van de Vliert, E., \& West, M. 2004. The bright and dark sides of individual and group innovation: A special issue introduction. Journal of Organizational Behavior, 25: 129-145.

[10] Janssen, O. (2000). Job demands, perceptions of effort-reward fairness and innovative work behavior. Journal of Occupational and Organizational Psychology, 73(3), 287-302.

[11] Gilson, L. L., \& Shalley, C. E. 2004. A little creativity goes a long way: An examination of teams' engagement in creative processes. Journal of Management, 30: 453470.

[12] Grant, A. 2008. Does intrinsic motivation fuel the prosocial fire? Motivational synergy in predicting persistence, performance, and productivity. Journal of Applied Psychology, 93(1), 48-58.

[13] Hair, J. F., W.C. Black, B.J. Babin, dan R.E. Anderson. 2010. Multivariate Data Analysis. 7th. New Jersey: Pearson Educational, Inc.

[14] Munton, A. G., \& West, M. A. 1995. Innovations and personal change: Patterns of adjustment to relocation. Journal of Organizational Behavior, 16(4), 363-375.

[15] Oldham, G. R., \& Cummings, A. 1996. Employee creativity: Personal and contextual factors at work. 
Academy of Management Journal, 39: 607-634.

[16] Thomas, K. W., \& Velthouse, B. A. 1990. Cognitive elements of empowerment: An "interpretive" model of intrinsic task motivation. Academy of Management Review, 15: 666-681.

[17] Tu, Y. D., \& Lu, X. X. 2013. How ethical leadership influence employees' innovative work behavior: A perspective of intrinsic motivation: Erratum. Journal of Business Ethics, 116(2), 457

[18] Yuan, F., \& Woodman, W, R. 2010. Innovative Behavior in the Workplace: The Role of Performance and Image Outcome Expectations. Academy of Management Journal.

[19] Shalley, C. E., Zhou, J., \& Oldham, G. R. 2004. The effects of personal and contextual characteristics on creativity: Where should we go from here? Journal of Management, 30: 933-958.

[20] Spreitzer, G. M. 1995. Individual empowerment in the workplace: Dimensions, measurement, validation. Academy of Management Journal, 38: 1442-1465.

[21] Spreitzer, G. M. 1996. Social structural characteristics of psychological empowerment. Academy of Management Journal, 39: 483-505.

[22] West, M.A. and Farr, J.L. 1989. Innovation at Work: Psychological Perspectives. Social Behavior, 4, 1530.

[23] Woodman, R. W., Sawyer, J. E., \& Griffin, R. W. 1993. Toward a theory of organizational creativity. Academy of Management Review, 18: 293-321.

[24] Zhou, J., \& Shalley, C. E. 2003. Research on employee creativity: A critical review and directions for future research. In J. Martocchio
(Ed.), Research in personnel and human resource management: 165217. Oxford, U.K.: Elsevier.

[25] Zhang, Xiaomeng., \& Bartol. Kathryn M. 2017. Linking Empowering Leadership and Employee Creativity: The Influence of Psychological Empowerment, Intrinsic Motivation, and Creative Process Engagement. Academy of Management Journal.53(1). 